Volume 13

Issue 3 Critical Genocide and Atrocity

Prevention Studies

$12-20-2019$

\title{
Moving Beyond the State: An Imperative for Genocide Prediction
}

Hollie Nyseth Brehm

The Ohio State University

Follow this and additional works at: https://digitalcommons.usf.edu/gsp

\section{Recommended Citation}

Nyseth Brehm, Hollie (2019) "Moving Beyond the State: An Imperative for Genocide Prediction," Genocide Studies and Prevention: An International Journal: Vol. 13: Iss. 3: 64-78.

DOI:

https://doi.org/10.5038/1911-9933.13.3.1673

Available at: https://digitalcommons.usf.edu/gsp/vol13/iss3/7

This Articles is brought to you for free and open access by the Open Access Journals at Digital Commons @ University of South Florida. It has been accepted for inclusion in Genocide Studies and Prevention: An International Journal by an authorized editor of Digital Commons @ University of South Florida. For more information, please contact digitalcommons@usf.edu. 


\section{Moving Beyond the State: An Imperative for Genocide Prediction}

\section{Acknowledgements}

Many thanks to all contributors of this special issue for their insightful comments, as well as the coeditors for organizing the special issue. Additional thanks to Genna Danial, who provided editing assistance with the references. 


\author{
Hollie Nyseth Brehm \\ The Ohio State University \\ Columbus, Ohio, USA
}

In the early hours of August 3, 2014, ISIL militants swept across the Sinjar region of northern Iraq, which is home to the majority of the world's Yazidi people. The next day, the Emir of the Yazidi pled for world leaders to intervene as ISIL kidnapped children and systematically massacred civilians. The entire male population of the village of Khocho was executed, while the Yazidi residents of another village were presented with an ultimatum: convert or be killed. ${ }^{1}$

Numerous scholars have called this violence genocide, ${ }^{2}$ and the International Association of Genocide Scholars deemed it a violation of the Convention on the Prevention and Punishment of the Crime of Genocide. ${ }^{3}$ Multiple early warning models of genocide, however, did not warn policymakers about these events. Iraq was not on the Atrocity Forecasting Project's list of 10 countries at risk of genocide between 2011 and 2015, ${ }^{4}$ nor was it in the top 10 countries Harff and Gurr predicted as at risk. ${ }^{5}$

Although there are several reasons behind this oversight, it is clear that early warning models ${ }^{6}$ are not designed to alert policymakers about genocides committed by non-state actors. Instead, these models typically evaluate whether genocide is likely to occur within a state; and they rely upon theories that were generated to explain state-led genocide and accompanying data measured at the state level. Such models and the theories undergirding them may consequently underperform in situations where violence was not committed by a state but rather by a non-state actor.

As the genocide committed by ISIL illustrates, state-centric assumptions that inform genocide prevention endeavors do not apply to every genocide. In line with this premise, this article argues that genocide forecasting efforts must move beyond the state-centrality that has characterized the field to date. It begins by addressing why predominant theories and corresponding genocide prevention efforts have largely focused on states. After describing the limits of a state-centric approach, I suggest three major avenues that will refine and complement the current state-centric paradigm that guides genocide prediction endeavors. These include 1) theorizing and analyzing non-state actors who commit genocide, 2) engaging in conflict-centered approaches, and 3) addressing the onset and triggers of genocide within subnational spaces. The article concludes with a discussion of how theory and research incorporating these proposals could ultimately contribute to more robust genocide prevention efforts.

\title{
State-Centric Approaches to Genocide Prediction
}

A long line of scholarship on genocide has established that the state-broadly defined in this article as an internationally recognized government and the territory it governs ${ }^{7}-$ is integral

${ }^{1}$ United Nations Human Rights Council, “They Came to Destroy: ISIS Crimes Against the Yazidis," Advance Version, 2016, (UN Doc. A/HRC/32/CRP.2), 6-8; Yazda Documentation Project, Mass Graves of Yazidis Killed by the Islamic State Organization or Local Affiliates On or After August 3, 2014, (Yazda: Global Yazidi Organization, 2016), 4.

${ }^{2}$ Fazil Moradi and Kjell Anderson, "The Islamic State's Yazidi Genocide in Iraq: The Sinjar Operations," Genocide Studies International 10, no. 2 (2016), 121; Sefik Tagay et al., "The 2014 Yazidi Genocide and its Effect on Yazidi Diaspora," The Lancet 390, no. 10106 (2017), 1946.

${ }^{3}$ International Association of Genocide Scholars, “Resolution on ISIS," March 18, 2016, accessed August 4, 2019, http:// genocidescholars.org/resources/resolutions.

${ }^{4}$ Atrocity Forecasting Project, “The Forecasts," Australian National University, updated December 18, 2017, accessed August 4, 2019, http://politicsir.cass.anu.edu.au/research/projects/atrocity-forecasting/forecasts.

${ }^{5}$ Genocide Prevention Advisory Network, “Home," accessed August 4, 2019, GPAnet.org.

${ }^{6}$ Although some people differentiate between early warning and forecasting models, I use both interchangeably to refer to efforts to predict the future occurrence of genocide.

${ }^{7}$ According to Max Weber, a state has the legitimate monopoly of the use of physical force in a given territory (see Max Weber, Politics as a Vocation (Philadelphia: Fortress Press, 1965) for more). Although non-state organizations like ISIL exercise force within a territory and can even perform some of a state's duties, I refer in this article to internationally recognized states that have garnered at least some legitimacy. 
to understanding the onset of genocide. ${ }^{8}$ Though the international legal definition of genocide does not restrict genocidal violence to state-led action, many genocides that occurred over the last century were committed by states, ${ }^{9}$ and others were undertaken with tacit state involvement. Moreover, states have historically used genocide as a form of repression. ${ }^{10}$

Researchers concerned with predicting genocide have accordingly focused on the state-level conditions that influence the possibility genocide could occur within a country. Some of this research has specifically addressed the government itself. For instance, comparative historical scholarship, like Rummel's Death by Government, ${ }^{11}$ has emphasized how the type of government influences the likelihood of genocide. As the state also includes the territory that a government controls, many other case studies have addressed additional country-level factors, such as a state's capacity across its territory. ${ }^{12}$

Such case studies were integral to the quantitative research that emerged during the 1990s and early 2000s as the cornerstone of genocide forecasting efforts. ${ }^{13}$ Generally, these models analyze country-level data and find that genocide is more likely in states with political upheaval, autocratic governments, exclusionary ideologies, contention regarding the ethnicity of those in power, stateled discrimination, ${ }^{14}$ and a prior history of genocide. Scholars have further refined these state-level factors - often in pursuit of informing genocide prediction efforts-over the past decade. Much of this work has identified the forms of upheaval that are most likely to influence genocide, such as assassinations, riots $^{15}$, and other crises $^{16}$-all measured at the state level. ${ }^{17}$ Other scholarship has specified a two-step model of the onset of genocide. For instance, Goldsmith and co-authors ${ }^{18}$ estimate the likelihood of instability within a country for a given year and then incorporate this estimate as a predictor in models of the likelihood of genocide. ${ }^{19}$ Straus and Valentino ${ }^{20}$ likewise

${ }^{8}$ Empires were certainly core to understanding genocide during colonialism, though I restrict this article to more recent genocides given my emphasis on early-warning and forecasting efforts tied to genocide prevention.

${ }^{9}$ Some scholarship does not disaggregate the state into its constituent parts, though the state is not monolithic and consists of numerous actors. Additional work should further disaggregate the state itself. For instance, Kim found that revolutionary leaders were more likely to commit mass killing, see Nam Kyu Kim, "Revolutionary Leaders and Mass Killing," Journal of Conflict Resolution 62, no. 2 (2018), 289.

${ }^{10}$ Christian Davenport, “State Repression and Political Order," Annual Review of Political Science 10 (2007), 1.

${ }^{11}$ Rudolph J. Rummel, Death by Government (New York: Transaction Publishers, 1997), 1-27.

${ }^{12}$ Far too many case studies have examined the causes of genocide to summarize here. I instead focus on quantitative models, as these models directly inform early warning systems and genocide prevention efforts.

${ }^{13}$ Helen Fein, "Accounting for Genocide after 1945: Theories and Some Findings," International Journal on Group Rights 1, no. 2 (1993), 79; Matthew Krain, "State-Sponsored Mass Murder: The Onset and Severity of Genocides and Politicides," Journal of Conflict Resolution 41, no. 3 (1997), 331; Barbara Harff, "No Lessons Learned from the Holocaust? Assessing Risks of Genocide and Political Mass Murder Since 1955," American Political Science Review 97, no. 1 (2003), 57; William Easterly et al., "Development, Democracy, and Mass Killing," Journal of Economic Growth 11, no. 2 (2006), 129.

${ }^{14}$ State-led discrimination was not included in the 2003 model but rather was added upon a later iteration in 2012.

${ }^{15}$ Nicolas Rost, "Will It Happen Again? On the Possibility of Forecasting the Risk of Genocide," Journal of Genocide Research 15, no. 1 (2013), 59.

${ }^{16}$ Gary Uzonyi, “Domestic Unrest, Genocide and Politicide," Political Studies 64, no. 2 (2016), 315; Gary Uzonyi, “Civil War Victory and the Onset of Genocide and Politicide," International Interactions 41, no. 2 (2015), 366; Hollie Nyseth Brehm, "Re-examining Risk Factors of Genocide," Journal of Genocide Research 19, no. 1 (2017), 62.

${ }^{17}$ Others have examined mass killings, which do not necessarily target a particular group. As noted in more detail below, I draw upon literature on mass killings due to the overlap between mass killing and genocide.

${ }^{18}$ Benjamin E. Goldsmith et al., "Forecasting the Onset of Genocide and Politicide: Annual Out-of-Sample Forecasts on a Global Dataset, 1988-2003," Journal of Peace Research 50, no. 44 (2013), 437-452.

${ }^{19}$ This model also included several novel predictors, such as the proportion of a country's population in the army and whether the country was in an election period.

${ }^{20}$ Valentino analyzed the triggers of 32 state-sponsored mass killings and concluded that anti-government protests, strikes, coups, and initial major attacks by rebels were among the most common triggers (see Benjamin Valentino, "Triggers of Mass Killing," Report on a Research Project for the Political Instability Task Force (Hanover: Dartmouth College, February 2016), 1). In a similar vein, Straus examined the triggers of 18 atrocity events, finding that threats to the political elite-such as battlefield advances, assassinations, coups, or protests - are among the most prominent triggers of mass atrocity (see Scott Straus, "Triggers of Mass Atrocities," Politics and Governance 3, no. 3 (2015), 5). Some 
each contribute to two-step models by examining triggers, or the events and processes that more immediately precede the onset of genocide, such as major attacks by rebels.

All of the aforementioned studies have examined genocide by analyzing state-level factors. This approach has been guided both by theories of genocide as well as by available data, as most major data collection efforts catalogue state level factors (e.g., Gross Domestic Product). In turn, the state-centric approach in scholarship directly influences genocide prediction efforts, which draw upon this research to create forecasting systems. For instance, the Political Instability Task Force (PITF) analyzes a dataset of country-years to produce a list of countries for policymakers to monitor. The University of Sydney's Atrocity Forecasting Project also generates lists of states at risk of genocide; GenocideWatch, Harff and Gurr's website, and many other atrocity forecasting undertakings assess risk at the state level as well. ${ }^{21}$ Put simply, when researchers and policymakers think about the risk of genocide, they tend to consider whether genocide could occur within a given state.

To be clear, these endeavors are not misguided, as the state is vital to understanding the onset of genocide. Government officials and their armies have initiated most genocides that occurred during the $20^{\text {th }}$ and $21^{\text {st }}$ centuries. Factors related to the state, such as the type of government or state capacity, can certainly influence the likelihood of genocide; and interventions in genocidesuch as economic sanctions and military sanctions - typically target the state. ${ }^{22}$

Genocide research and related prediction efforts nonetheless run the risk of placing undue emphasis on the state. Multiple genocide scholars have previously pointed out the state-centricity that has continued to dominate genocide studies. ${ }^{23}$ This article extends their critiques by exploring how state-centricity has affected forecasting efforts with a specific focus on suggesting how to transcend this state-centricity in favor of better genocide prediction. As noted in the introduction, limiting early warning models to violence committed by the state disregards the fact that non-state actors can and do commit genocide. Predicting the onset of genocide at the state-level also eclipses other meaningful ways to examine genocide, such as at the conflict-level since there can be multiple conflicts with a state at any given time. Furthermore, although the state is a meaningful concept in international relations, genocide often occurs in only part of a state or unfolds differently in separate regions. For instance, the genocide in Sudan that began in 2003 was limited to the Darfur region. Even in instances where genocide envelops an entire country, the violence often begins earlier in certain parts of the country, though early warning efforts rarely focus on subnational spaces.

Thus, as a complement to state-centric approaches to genocide prediction, this article suggests three core ways in which genocide prediction efforts should expand beyond the state, both in theory and in research on genocide onset, which is key for genocide forecasting. These three paths include 1) addressing genocide committed by non-state actors, 2) taking conflicts as the unit of analysis and analyzing how characteristics of a conflict influence the onset of genocide, and 3) examining the onset and triggers of genocide at subnational levels, such as within communities. For each, I incorporate interdisciplinary scholarship that has focused on genocide, defined as actions taken with the intent to destroy, in whole or in part, a social group. ${ }^{24} \mathrm{I}$ also integrate research on

of these factors, like assassinations or coups, have been included as structural factors in other models, indicating that triggers may be built into some models that do not claim to engage in two-step analyses.

${ }^{21}$ Notably, the United Nations does not restrict its forecasting to countries, but the vast majority of the factors incorporated into its framework are state-level factors, such as situations that place the state under stress or discriminatory state policies.

${ }^{22}$ Matthew Krain, "The Effects of Diplomatic Sanctions and Engagement on the Severity of Ongoing Genocides or Politicides," Journal of Genocide Research 16, no. 1 (2014), 26; Matthew Krain, "The Effect of Economic Sanctions on the Severity of Genocides or Politicides," Journal of Genocide Research 19, no. 1 (2017), 88.

${ }^{23}$ Alexander Laban Hinton, "Critical Genocide Studies," Genocide Studies and Prevention 7, no. 1 (2012), 10; Cyanne Loyle, "Understanding Nonstate Actor Behavior: The Determinants of Mass Atrocities," Simon-Skjodt Center for the Prevention of Genocide Series of Occasional Papers, no. 9 (2018), 2.

${ }^{24}$ This includes the four groups specified in the United Nations Convention on the Prevention and Punishment of the Crime of Genocide as well as other social groups, such as political groups, as group membership is socially constructed. 
mass killings and other atrocities given the similarities across these forms of violence and use the respective authors' terms (e.g., mass atrocity, mass killing, civilian targeting) when referencing their findings. To be certain, genocide studies has sometimes been siloed such that relevant research on related types of violence - such as civil wars or terrorism - is not considered alongside the study of genocide. A critical engagement with genocide prevention involves breaking down disciplinary barriers in favor of a more holistic view of the study of violence.

Each of the subsequent sections also includes specific suggestions for future research that should in turn inform forecasting - research that should be informed by a multitude of methods. Quantitative, large-N models are often necessary to establish more general patterns in social processes. In fact, the early warning and risk assessment models reviewed by Verdeja in this special issue rely almost exclusively on quantitative analyses. The numbers employed in such models are powerful, but they are also reductive, erase lived experiences, and privilege violence that is easily quantified. ${ }^{25}$ Analyses of general patterns should consequently be complemented with rich, contextualized information. As such, I provide suggestions for how researchers can leverage the benefits of diverse methods when analyzing non-state actors, conflicts, and subnational spaces.

\section{Non-State Actors}

The violence undertaken by insurgent groups, terror organizations, militias, and other non-state actors can equal or even surpass that committed by states. ${ }^{26}$ Some of this violence straddles the line between intentional and unintentional targeting and has consequently been framed as collateral damage by researchers. ${ }^{27}$ Other non-state violence against civilians is undoubtedly intentional, and as ISIL's violence against the Yazidi makes clear, this violence can take the form of genocide.

ISIL is not the first non-state actor to commit genocide. Indeed, the Political Instability Task Force database includes a genocide in 1964 in the Democratic Republic of the Congo, noting in its explanation that "rebels massacre(d) counter-revolutionaries, including educated Congolese, missionaries, and other Europeans." ${ }^{28}$ The Lord's Resistance Army (LRA) has likewise arguably committed genocide by targeting the Acholi people in Northern Uganda. ${ }^{29}$

In each of these instances, a non-state actor instigated the genocide, commonly in spaces where the state lacked capacity. In this sense, they differ from the non-state actors that work alongside other actors (like states) that initiate genocide, though these non-state actors do often attempt to act like states themselves. They levy taxes, take territory, and wield an army in pursuit of creating their own state despite lack of international recognition. ${ }^{30}$ It stands to reason that such groups would have the capacity to initiate and commit genocides - a capacity that is no longer limited to states.

Genocide researchers should consequently theorize why non-state actors initiate genocide and examine the conditions under which they do (and do not). These theories, in turn, can inform research on the onset of genocide at the group-level. Before addressing existing theories and data that could inform these efforts, however, it is important to recognize that non-state actors are heterogeneous - something that is often masked by framing all of these groups as non-state actors simply in reference to states. Indeed, militias, rebel groups, terror organizations, and other nonstate actors vary widely in terms of their degree of organization, size, scope, membership, and aims, among other factors. Given these distinctions and a lack of scholarly agreement about how to classify non-state actors, I use the term "non-state actor" to refer generally to any or all of these groups.

With this caveat in mind, efforts to theorize and analyze genocides committed by non-state actors may be informed by scholarship that examines why non-state actors engage in widespread, systematic targeting of civilians. Much like research on genocide, this work has addressed why non-state actors target civilians by theorizing strategic reasons behind their actions as well as assessing the situations in which non-state actors do and do not harm civilians. ${ }^{31}$ Although there may be important differences to uncover between genocidal violence and other forms of systematic violence against civilians, this scholarship suggests that genocide initiated by non-state actors may

\footnotetext{
${ }^{31}$ Benjamin A. Valentino, "Why We Kill: The Political Science of Political Violence Against Civilians," Annual Review of Political Science 17, no. 1 (2014), 93; this violence can also be driven by non-strategic factors, like greed (see Weinstein) or retaliation (see Gould).
} 
be linked to characteristics of the non-state actor, the non-state actor's relationships, or the broader structural context.

Turning first to the group characteristics, non-state actors' violence against civilians has been linked to the internal structure of the group, including an amorphous organizational structure and a leadership deficit. ${ }^{32}$ Group capacity may likewise matter, with comparatively weaker groups found to be more likely to engage in violence against civilians. ${ }^{33}$ A group's ideology may also influence civilian targeting, and scholarship on terror organizations has found that religious and ethno-nationalist ideologies can be particularly deadly. ${ }^{34}$ Indeed, the violence committed by ISIL was motivated by a particular ideological worldview, not unlike the genocides committed by the Khmer Rouge or Nazi Germany. ${ }^{35}$

The non-state actors' relationships with other actors-most notably, civilians and governments - may also affect whether they turn to genocide. With regard to relationships with civilians, non-state actors may target civilians who appear supportive of their enemies. ${ }^{36}$ As Schwartz and Straus suggest, ${ }^{37}$ such violence may be genocidal when the non-state actor views civilians as unwinnable and consequently seeks to eradicate them. ${ }^{38}$ Non-state actors may also engage in violence against civilians due to their relationships with governments. For instance, nonstate actors that benefit from state support may be more likely to commit genocide, since states often use rebel groups to commit violence and since many non-state organizations, such as terror organizations, depend on financial support from states..$^{39}$ Of course, non-state actors frequently commit genocidal violence alongside or on behalf of another actor, as scholarship on the Janjaweed in Darfur or Arkan's Tigers in Bosnia has illustrated. ${ }^{40}$ Here, I focus on non-state actor initiated violence rather than these and other cases where the non-state actor carries out violence initially begun by others, but I recognize the line between state and non-state is often blurred and that ties between actors may change over time. ${ }^{41}$

Finally, studies of the onset of genocide committed by non-state actors may benefit from the existing scholarship that focuses on state-level, structural factors that influence the onset of genocide. Put simply, these groups do not operate in a vacuum, and other dynamics - such as the type of government in the state (or states) in which they operate, the presence of a civil war, or the number of other non-state actors operating within a defined space-may play a role. Wood ${ }^{42}$

${ }^{32}$ Macartan Humphreys and Jeremy M. Weinstein, "Handling and Manhandling Civilians in Civil War," American Political Science Review 100, no. 3 (2006), 429-447; Max Abrahms and Philip B K Potter, "Explaining Terrorism: Leadership Deficits and Militant Group Tactics," International Organization 69, no. 2 (2015), 311-342.

${ }^{33}$ Wood, Rebel Capability, 601-614.

${ }^{34}$ Victor Asal and R. Karl Rethemeyer, "The Nature of the Beast: Organizational Structures and the Lethality of Terrorist Attacks," The Journal of Politics 70, no. 2 (2008), 437-449.

${ }^{35}$ Eric D. Weitz, A Century of Genocide (Princeton: Princeton University Press, 2003), 8-15.

${ }^{36}$ Jeff Goodwin, “A Theory of Categorical Terrorism," Social Forces 84, no. 4 (2006), 2027-2046; Lisa Hultman, "Attacks on Civilians in Civil War: Targeting the Achilles Heel of Democratic Governments," International Interactions 38, no. 2 (2012), 164-181.

${ }^{37}$ Rachel A. Schwartz and Scott Straus, "What Drives Violence Against Civilians in Civil War? Evidence from Guatemala's Conflict Archives," Journal of Peace Research 55, no. 2 (2018), 222-235.

${ }^{38}$ Non-state actors may also target civilians to coerce them into providing support or withholding support for another actor (see Azam and Hoeffler, Kalyvas and Kocher), though this may be less likely to coincide with genocidal aims.

${ }^{39}$ Idean Salehyan, "The Delegation of War to Rebel Organizations," Journal of Conflict Resolution 54, no. 3 (2010), 493515; Non-state violence against civilians can also be part of a coercive strategy to inflict costs on governments and harm political adversaries. Rebel or terror groups may also resort to violence against civilians when they are too weak to challenge government military forces directly (see Lisa Hultman, "Battle Losses and Rebel Violence: Raising the Costs for Fighting," Terrorism and Political Violence 19, no 2 (2007), 205). These motivations may appear incompatible with genocide, though the choice of whom to target and the forms of destruction may still be genocidal in nature. Additionally, the presence of one motivation - in this case, targeting the government-does not mean that motivations cannot be multifaceted and cannot also involve the intent to destroy a group.

${ }^{40}$ Julie Flint, Beyond "Janjaweed": Understanding the Militias of Darfur (Geneva: Small Arms Survey, 2009), 16-29; Alex Alvarez, "Militias and Genocide," War Crimes, Genocide \& Crimes Against Humanity 2, no. 1 (2006), 1-33.

${ }^{41}$ Relatedly, there would also be value in modeling when governments use militias to carry out their violence.

${ }^{42}$ Wood, Rebel Capability, 601. 
illustrates that civilians are more likely to be victimized when a weak insurgent group faces a strong government, for instance, while Loyle ${ }^{43}$ finds that mass atrocities committed by non-state actors occur in contexts where states also commit mass atrocities.

Researchers should consequently take non-state actors as the unit of analysis, and forecasting efforts could consider the various factors that make certain non-state actors more likely to commit genocide. These analyses could also take a two-step approach that couples structural factors with the triggers of genocide committed by non-state actors. For instance, in an ongoing project, several colleagues and I have been conducting in-depth case studies of the catalysts of mass killings committed by non-state actors in Africa. Our process tracing addresses why Lord's Resistance Army (LRA) members killed hundreds of civilians in December 2008, and they find that this sharp uptick in LRA violence against civilians came two weeks after the announcement of Operation Lightning Thunder, a joint military operation targeting the LRA. Aligning with this, and based on 26 other case studies, we argue that opposition military advances are the most prominent triggers of mass killings committed by non-state actors. This, in turn, suggests that threat may be a particularly important trigger of violence committed by non-state actors.

Numerous datasets exist to aid researchers in assessing the group characteristics, relational factors, and structural factors that may influence the onset of genocide committed by non-state actors. The Uppsala Conflict Data Program (UCDP)'s Armed Conflict Dataset contains valuable information about violence committed by non-state actors, while the Non-State Actor Dataset includes characteristics of groups that are in UCDP's data. ${ }^{44}$ The Non-State Armed Groups Dataset (NAGS) and the Dangerous Companions Project encompass important information about state support given to non-state armed groups as well as group characteristics, such as ideology. Finally, some non-state actors' links to states can be found in the Pro-Government Militia (PGM) database.

These datasets are admittedly limited to established non-state actors. Militias and other groups that are in their infancy or are more loosely organized are consequently not included, underscoring the importance of employing case studies of non-state actors alongside endeavors that rely upon quantitative datasets. Even with established actors, such as ISIL, quantitative modeling should be paired with in-depth analyses of processes and contexts in efforts to test and build theory, as well as in efforts to predict the onset of genocidal violence by non-state actors.

\section{Conflicts}

Societal upheaval is typically seen as a predictor of genocide..$^{45}$ In fact, several studies have found that conflict, especially civil war, is the strongest predictor of genocide. ${ }^{46}$ Yet, while state-centric theories and models of genocide often include a measure of conflict, they often do not address differences between multiple conflicts within the same state. For instance, most datasets cite two different civil wars occurring in Ethiopia in 1976, though only one of these conflicts also involved genocide. According to the PITF database, ${ }^{47}$ a year after the civil war began in 1975, "army, internal security units, and civilian defense squads massacre(d) political and military elites, workers, students, bureaucrats, and others thought to oppose the revolutionary regime." However, when this genocide began, the Eritrean-Ethiopian war of independence was also taking place. This civil war was separatist in nature, though it did not involve genocide.

State-level factors cannot account for why one of these civil wars involved genocide while the other did not, but in-depth comparative case studies of the two conflicts likely can. Additionally, quantitative or comparative qualitative analyses of the onset of genocides in certain conflicts could shed light on the types of conflicts that may lead to genocide, either as the conflicts are ongoing or in their aftermath. Researchers should consequently devote additional attention to the conflict-

\footnotetext{
${ }^{43}$ Loyle, Understanding Nonstate Actor Behavior, 16.

${ }^{44}$ Mihai Croicu and Ralph Sundberg, UCDP Georeferenced Event Dataset Codebook. Version 5.0 (Uppsala: Department of Peace and Conflict Research, Uppsala University, 2016).

${ }^{45}$ Harff, No Lessons Learned from the Holocaust?

${ }^{46}$ Krain, State-Sponsored Mass Murder; Nyseth Brehm, Re-examining Risk Factors, but see Williams.

${ }^{47}$ PITF, State Failure Problem Set (full citation available from the author).
} 
related factors that influence the onset of genocide, ${ }^{48}$ and genocide prevention models should address when conflicts lead to genocide, and, equally importantly, when they do not. In such analyses, characteristics of the conflicts - rather than the countries - should be prioritized. These characteristics include but are not limited to the type of conflict, who is involved, aspects of the violence itself, and, for genocides that begin after a conflict ends, how the conflict came to a close.

Perhaps most notably, mass killing of civilians is more likely during certain types of conflicts. Valentino, Puth, and Blach-Lindsay ${ }^{49}$ argue that mass killing is more prominent in conflicts where guerrilla armies oppose governments. Yet, $\mathrm{Krcmaric}^{50}$ finds the exact opposite, arguing that mass killing is more probable during conventional wars than during guerilla wars. Scholars could test these competing hypotheses for the case of genocide, which in turn may shed light on such divergent findings. Additionally, scholars could examine whether other types of conflicts, such as ethno-nationalist conflicts, are more likely to include genocide.

Closely aligned with this, researchers could assess whether the changing nature of war influences the onset of genocide. Walter ${ }^{51}$ suggests that there have been three recent waves of civil wars: one that began around 1951 and ended with the Cold War, a second that began around 1992, and a third that began with the fall of Saddam Hussein in 2003. She argues that each of these periods is distinguished by civil wars with distinct attributes, focusing largely on ideological aims. As such, scholars could examine whether the characteristics of the third wave of wars are particularly relevant to understanding the onset of genocide in the $21^{\text {st }}$ century.

Beyond the type of conflict, the actors involved may also influence whether genocide is likely to occur during or after a conflict. For instance, the group characteristics of non-state actors involved in the conflict-such as their motivating ideology or their structure-may play a role. Factors indicative of threat to the state may be particularly important; perhaps conflicts involving larger non-state actors or non-state actors that garner widespread public support are more likely to involve genocide. The historical legacies of who is involved in the conflict may likewise shape the possibility of genocide, as these legacies may inform perceptions of threat as well as perceptions of support for various actors. Furthermore, the internationalization of conflict, including financial support from external parties, may also matter. Gleditsch ${ }^{52}$ illustrates, for example, that many civil wars are transnational in terms of actors and resources; and scholars could examine how foreign support during conflict-in terms of who provides such support and the level of supportinfluences the likelihood that conflict leads to genocide.

Aspects of the violence itself should also be addressed. Researchers could assess whether the intensity of violence influences the onset of genocide. The geographic distribution of violence may similarly prove influential, as governments or non-state actors may be more likely to engage in genocide when conflicts threaten spaces they value, such as locations rich with natural resources or of other geo-political importance. Furthermore, researchers could examine the length of time between the onset of conflict and genocide, addressing why some conflicts immediately involve genocide while others lead to genocide years after the conflict began or, in some cases, after the conflict ended.

Finally, distinct factors may affect the genocides that begin after a conflict ends. Uzonyi ${ }^{53}$ artfully shows that civil wars with a clear victor are more likely to see their winning party engage in genocide than conflicts that end through other means, such as negotiations. Aspects of negotiations may also impact the likelihood of genocide. For example, many scholars suggest the Arusha

\footnotetext{
${ }^{48}$ Thankfully, several scholars have begun this process, though genocide prevention efforts have yet to incorporate their findings or to model onset of genocide at the conflict-level.

${ }^{49}$ Benjamin Valentino et al., “'Draining the Sea': Mass Killing and Guerrilla Warfare,” International Organization 58, no. 2 (2004), 375-407.

${ }^{50}$ Daniel Krcmaric, "Varieties of Civil War and Mass Killing: Reassessing the Relationship between Guerrilla Warfare and Civilian Victimization," Journal of Peace Research 55, no. 1 (2018), 18-31.

${ }^{51}$ Barbara F. Walter, "The New New Civil Wars," Annual Review of Political Science 20, (2017), 469-486.

${ }^{52}$ Kristian Skrede Gleditsch, "Transnational Dimensions of Civil War," Journal of Peace Research 44, no. 3 (2007), $293-309$.

${ }^{53}$ Uzonyi, Civil War Victory, 366.
} 
Accords influenced the onset of the 1994 genocide in Rwanda, ${ }^{54}$ and the aspects of peace treaties that lead to genocide could be informed by scholarship on peace treaties and conflict recurrence more broadly. ${ }^{55}$

To be certain, distinguishing between civil wars and genocides can be analytically tricky, and this difficulty is compounded by the fact that genocide is a political, contested concept. For instance, the International Criminal Tribunal for the Former Yugoslavia deemed the 1995 massacre at Srebrenica that occurred during the Bosnian civil war as genocide. Others label additional aspects of the civil war that unfolded in different parts of the country, like the violence in the Northwest region of Prijedor, as genocide as well. ${ }^{56}$ Such disagreements must be kept in mind, but scholarly arguments regarding the nature of violence may also influence the creation of better tools to measure forms of violence that are deeply intertwined and unfold simultaneously.

Thus, to analyze whether and why certain conflicts lead to genocide - including the type of conflict, who is involved, aspects of the violence itself, and how the conflict ended - researchers could draw upon the impressive databases that have documented global conflicts to date. Peace Research Institute Oslo (PRIO) has created numerous datasets that track various forms of armed conflict, often in collaboration with the Uppsala Conflict Data Program (UCDP). The Major Episodes of Political Violence (MEPV) Dataset likewise documents large-scale violence, while UCDP also introduced a conflict termination dataset that contains information about how conflicts come to an end.

Once again, conflict-centered endeavors should likewise rely on case-based analyses that privilege local knowledge and context. For example, my own preliminary qualitative comparative analyses suggest that separatist conflicts are much more likely to lead to genocide than other forms of conflicts. Much more could be done to trace the events that unfolded in conflicts that did involve or lead to genocide alongside those that did not, however, in order to better understand the processes that are associated with the onset of genocide.

\section{Subnational Spaces}

Lastly, although genocides are typically accorded a country-level onset date, violence can begin at various times within each country or, conceivably, across countries (such as on both sides of a border). In order to predict the onset of genocide with more precision, researchers must understand why violence starts in specific locations. While state-level factors such as a state-led exclusionary ideology or threat to a government may inform why genocide occurs within a state, they cannot fully explain why violence begins at a particular location, as these factors provide no information pertaining to spaces below the state-level. In fact, extending these factors to subnational units would neglect the fact that those committing the violence are, like all social actors, subject to the influence of their immediate social surroundings-surroundings that vary widely.

As Figure 1 illustrates, although the 1994 genocide in Rwanda began almost immediately after the president's plane was shot down on the night of April 6, violence started earlier in some places of the country. McDoom ${ }^{57}$ suggests that elite competition for control and ethnic segregation influenced this variation in onset, while Straus ${ }^{58}$ finds that violence began earlier in areas with lower unemployment rates. Focusing on the spread of information, Nyseth Brehm ${ }^{59}$ suggests that Radio RTLM (a hate-speech radio) coverage is also associated with earlier onset.

Though the studies cited in the prior paragraph employ quantitative analyses to assess the factors associated with subnational onset of genocide, case studies of subnational spaces are also informative. For instance, the large area in southwestern Rwanda with the latest onset was known

\footnotetext{
${ }^{54}$ Catharine Newbury, “Background to Genocide: Rwanda," African Issues 23, no. 2 (1995), 12-17.

${ }^{55}$ Barbara F. Walter, “Designing Transitions from Civil War: Demobilization, Democratization, and Commitments to Peace," International Security 24, no. 1 (1999), 127-155.

${ }^{56}$ Edina Bećirević, Genocide on the Drina River (New Haven: Yale University Press, 2014), 68.

${ }^{57}$ Omar Shahabudin McDoom, "Predicting Violence within Genocide: A Model of Elite Competition and Ethnic Segregation from Rwanda," Political Geography 42 (2014), 34-45.

${ }^{58}$ Scott Straus, The Order of Genocide: Race, Power, and War in Rwanda (Ithaca: Cornell University Press, 2006), 61.

${ }^{59}$ Hollie Nyseth Brehm, "Conditions and Courses of Genocide" (PhD. diss., University of Minnesota, 2014), 148.
} 
as Butare. Butare was a former prefecture (a region somewhat akin to a state) and was the only one of Rwanda's prefectures led by a Tutsi prefect (a position somewhat akin to a governor). When the genocide began, the prefect tried to resist the violence. Although genocide was unfolding in most parts of the country, the prefect met with Butare's local leaders and encouraged them to prevent violence and help others. On April 17, however, Rwanda's interim government removed the prefect from his position. ${ }^{60}$ Violence in Butare began almost immediately afterward, ${ }^{61}$ illustrating the importance of leaders in influencing subnational onset.

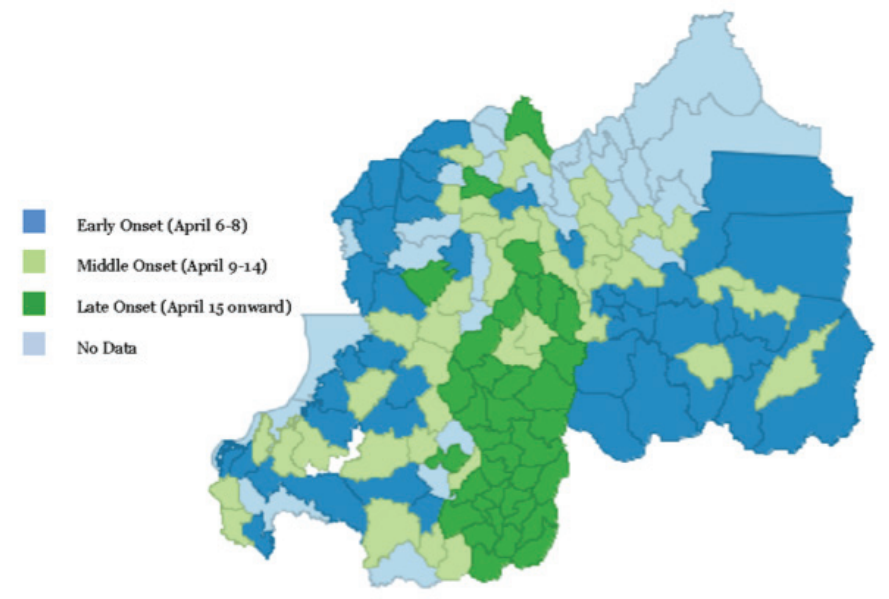

Figure 1. Commune Onset of Genocide in 1994 Rwanda

Being able to pinpoint where genocide will begin with more precision than the state-level could have many benefits for genocide prevention efforts, and theories about where genocide starts could be guided by scholarship on localized civil conflict and crime. Specifically, recent analyses of civil and ethnic violence have documented how subnational dynamics influence where and when violence occurs. ${ }^{62}$ For instance, Buhaug and colleagues ${ }^{63}$ found that the onset of civil conflict was more likely in subnational spaces marked by low economic growth and capacity, while Fjelde and Uexkull ${ }^{64}$ argue that climate variability heightens subnational conflict. Furthermore, Buhaug and Rød ${ }^{65}$ examined disaggregated data across Africa and found that separatist conflicts were more likely to occur in sparely populated regions near borders and comparatively far from capital cities. ${ }^{66}$

${ }^{60}$ Allison Des Forges, Leave None the Tell the Story: Genocide in Rwanda (New York: Human Rights Watch, 2009), 209.

${ }^{61}$ Violence had already begun in the commune of Nyakizu, however.

${ }^{62}$ Elisabeth Jean Wood, Insurgent Collective Action and Civil War in El Salvador (New York: Cambridge University Press, 2003), 226-256; Stathis Kalyvas, The Logic of Violence in Civil War (New York: Cambridge University Press, 2006), 388392; Alok K Bohara et al., "Opportunity, Democracy, and the Exchange of Political Violence: A Subnational Analysis of Conflict in Nepal," Journal of Conflict Resolution 50, no. 1 (2006), 108-128; Gudrun Østby et al., "Population Pressure, Horizontal Inequality and Political Violence: A Disaggregated Study of Indonesian Provinces, 1990-2003," The Journal of Development Studies 47, no. 3 (2011), 377-398; Siri Camilla Aas Rustad et al., "All Conflicts is Local: Modeling SubNational Variation in Civil Conflict Risk," Conflict Management and Peace Science 28, no. 1 (2011), 15-40.

${ }^{63}$ Halvard Buhaug et al., "Geography, Rebel Capability, and the Duration of Civil Conflict," Journal of Conflict Resolution 53, no. 4 (2009), 544-569.

${ }^{64}$ Hanne Fjelde and Nina von Uexkull, “Climate Triggers: Rainfall Anomalies, Vulnerability and Communal Conflict in Sub-Saharan Africa," Political Geography 31, no. 7 (2012), 444-453.

${ }^{65}$ Halvard Buhaug and Jan Ketil Rød, "Local Determinants of African Civil Wars, 1970-2001," Political Geography 25, no. 3 (2006), 315-335.

${ }^{66}$ Clionadh Raleigh and Håvard Hegre, "Population Size, Concentration, and Civil War: A Geographically Disaggregated Analysis," Political Geography 28, no. 4 (2009), 224-238; this does not mean that state-level factors, such as type of 
Combining insights from numerous studies, Rustad and co-authors ${ }^{67}$ propose a subnational conflict risk indicator based on population, socioeconomic status, conflict history, ethno-political exclusion, geographic location within a country, and neighboring conflicts in other subnational administrative units. $^{68}$ Such factors may likewise inform the subnational risk of genocide. Furthermore, the subnational levels or forms of civil conflict themselves may also influence where genocide unfolds and the timing of this violence.

Studies of the subnational onset of genocide could likewise draw inspiration from theories of criminology. The notion that crime unfolds differently in distinct places has long been a hallmark of criminological inquiry. In fact, criminologists have found there are hot spots in crime, or subnational areas that consistently experience comparatively more violent crime. In Minneapolis, Minnesota, for example, three percent of neighborhoods were responsible for 50 percent of crimes in $1986 .{ }^{69}$ Hot spots likewise exist on a worldwide scale, and recent research has also found hot spots may be linked to riots. ${ }^{70}$ Data on hot spots may be useful for predicting where genocide begins, and at a minimum, scholars should address whether there are certain hot spots of genocidal violence as well.

Ecological studies of crime have also pointed toward many other structural factors (such as employment levels, community cohesion, and signs of social and physical disorder) that could influence the onset of violence at various subnational levels. Such data may be particularly useful in predicting the onset of violence that is largely undertaken by civilians, as was the case in Rwanda. Indeed, Nyseth Brehm ${ }^{71}$ illustrates that characteristics of communities, like marriage rates, informed levels of in violence in Rwanda. These factors may also be relevant for understanding the onset of genocide.

Finally, triggers could also be analyzed at subnational levels. The triggers of genocide have thus far been conceptualized at the state-level, but in much the same way, these events and processes likely occur in localized spaces. Are there subnational triggers, and do they differ from those typically accorded on a national level? For instance, the trigger of the 1994 genocide in Rwanda was the president's plane crash, but there may have been more proximate, localized triggers in the communities depicted in Figure 1.

Data that could be used in studies of subnational onset and triggers are increasingly available. Most datasets of civil war include disaggregated conflict data (for instance, see the Armed Conflict Location Event Dataset Project, or ACLED), and many datasets are beginning to geo-reference events, such as protests or riots (e.g., the Social Conflict in Africa Database). National censuses worldwide often include indicators of population, employment, and ethnicity and are typically available through IPUMS International. Furthermore, a 2017 issue of American Behavioral Scientist considered how to measure state capacity in subnational spaces, while many environmental indicators - such as rainfall and average temperatures - can easily be mapped onto subnational spaces using GIS programs.

That said, researchers should not be restricted by the pre-set, subnational boundaries that dictate the information available in quantitative datasets, such as census tracts and other administrative areas. Though these data can be useful, subnational administrative units and their boundaries are often created through political processes and may not hold meaning for their residents. Fieldwork could shed light on how people living within these areas view their communities and whether and how such communities map onto administrative boundaries, which in turn may dictate which subnational level to consider.

government, cannot be considered. These should be considered as the first step. Nevertheless, aggregating data across a country can obscure valuable information, especially when the violence is not initiated by the state.

${ }^{67}$ Rustad et al., All Conflict is Local.

${ }^{68}$ The latter two are given less weight in the index.

${ }^{69}$ Lawrence W. Sherman, "Hot Spots of Crime and Criminal Careers of Places," Crime and Place 4, (1995), 35-52.

${ }^{70}$ Peter Baudains et al., "Geographic Patterns of Diffusion in the 2011 London Riots," Applied Geography 45, (2013), $211-219$.

${ }^{71}$ Hollie Nyseth Brehm, "Subnational Determinants of Killing in Rwanda," Criminology 55, no. 1 (2017), 5-31. 


\section{Implications for Genocide Prediction and Prevention}

This article has argued that state-centricity has characterized genocide forecasting and that, in order to pursue more accurate genocide prediction endeavors, researchers should look beyond the state. I have proposed three major paths for doing so, including 1) theorizing and analyzing nonstate actors who commit genocide, 2) engaging in conflict-centered approaches, and 3) addressing the onset and triggers of genocide within subnational spaces. Researchers examining these three areas should employ a multitude of methods, and they should draw insights from interdisciplinary scholarship on varying forms of violence, such as civilian targeting and mass killing.

Additionally, although I have addressed each of the three avenues in isolation, researchers and practitioners involved in genocide prevention efforts should examine them concurrently when possible. Moving from findings documented in research to forecasting future events is hardly an easy task, and others have identified some of its pitfalls. ${ }^{72}$ Though some of these drawbacks are tied to specific quantitative modeling decisions that are difficult to overcome (as all research methods have some drawbacks), in-depth knowledge about cases can help transcend some of the other pitfalls of forecasting genocide. For instance, large-N forecasting endeavors of non-state actors, conflicts, and subnational spaces can identify actors, conflicts, and spaces that may be at risk of genocide. These general analyses capture general patterns and trends, however, and are unable to consider rich, case-specific information. Consequently, these analyses should be complemented by situational and context-driven analyses of non-state actors, conflicts, and subnational spaces in order to refine risk assessments based on localized knowledge.

In the case of ISIL's genocide against the Yazidi that was briefly covered at the outset of this article, a dataset of armed actors likely would have enabled analysis of how ISIL's ideology, relationships, and broader situation may have influenced the group's likelihood of committing genocide. Such analyses could have been combined with process tracing that would have identified reasons behind ISIL's declaration of a caliphate a month prior to the genocide, which coincides with their escalation in violence and may have triggered the violence that occurred in August 2014. Analyses of the civil war that began in Iraq earlier that year may have likewise yielded important information linked to the type of violence that was unfolding. Furthermore, as the genocide targeting Yazidi was geographically concentrated, researchers could have been assessing whether certain parts of the country were more likely to experience violence. Of course, hindsight is clearly at play with this example, but the important point is that more refined information that transcends the state will aid prediction efforts.

To be certain, the three avenues proposed in this article are not exhaustive. There are many other factors that researchers should consider when analyzing the onset of genocide and, relatedly, assessing its risk. For instance, researchers could focus on groups that may be at risk of genocide. The Minorities at Risk Project contains information on groups that have suffered from discrimination, though grounded analyses would likewise be necessary given the socially constructed nature of groups. ${ }^{73}$ Case studies tracking group characteristics as well as the actions that have harmed groups may also wield important information. For instance, although the genocide against the Rohingya arguably began recently, Myanmar's government has discriminated against Rohingya people for decades.

Furthermore, as researchers focus on a particular phenomenon within a bounded period of time and space-such as a conflict, subnational region, or perhaps a group - they must remain cognizant of other factors at play, such as the involvement of international actors. To be sure, scholars of globalization have long suggested that the local and the global do not exist on their own. ${ }^{74}$ For instance, Goodale ${ }^{75}$ argues that researchers often uncritically employ the notion of a

\footnotetext{
${ }^{72}$ Michael D. Ward et al., "The Perils of Policy by P-Value: Predicting Civil Conflicts," Journal of Peace Research 47, no. 4 (2010), 363-375.

${ }^{73}$ Joan Esteban et al., "Strategic Mass Killings," Journal of Political Economy 123, no. 5 (2015), 1087-1132.

${ }^{74}$ Doreen Massey, A Global Sense of Place (Minneapolis: University of Minnesota Press, 1994), 1-2.

${ }^{75}$ Mark Goodale, “Locating Rights: Envisioning Law Between the Global and the Local," in The Practice of Human Rights: Tracking Law Between the Global and the Local, eds. Mark Goodale and Sally Engle Merry (New York: Cambridge University Press, 2007), 1-38.
} 
local, a national, and an international level without recognition that no location is fully detached from national and international processes. ${ }^{76}$ Though the use of levels can be useful for thinking about a complex world, researchers should nonetheless continue to recognize the multiplicity of processes at play in any given context.

Taken together, genocide prediction and related prevention endeavors are still quite new. Researchers can contribute to these paramount efforts by continually striving to better understand why genocide occurs. This starts by examining the onset of genocide, and analyses looking beyond the state to non-state actors, conflicts, and subnational spaces wield much promise.

\section{Acknowledgements}

Many thanks to all contributors in this special issue for their insightful comments, as well as the coeditors for organizing the special issue. Additional thanks to Genna Danial, who provided editing assistance with the references.

\section{Bibliography}

Abrahms, Max and Philip B.K. Potter. "Explaining Terrorism: Leadership Deficits and Militant Group Tactics." International Organization 69, no. 2 (2015), 311-342. Doi: 10.1017/ $\underline{\text { s0020818314000411 }}$

Alvarez, Alex. "Militias and Genocide." War Crimes Genocide \& Crimes Against Humanity 2, no. 1 (2006), 1-33.

Andreas, Peter and Kelly M. Greenhill. Sex, Drugs, and Body Counts: The Politics of Numbers in Global Crime and Conflict. Ithaca: Cornell University Press, 2010. Doi: 10.7591/9780801458309-013

Asal, Victor and R. Karl Rethemeyer. "The Nature of the Beast: Organizational Structures and the Lethality of Terrorist Attacks." The Journal of Politics 70, no. 2 (2008), 437-449. Doi: 10.1017/ $\underline{\text { s0022381608080419 }}$

Atrocity Forecasting Project. "The Forecasts." Australian National University. Updated December 18, 2017. Accessed August 4, 2019. http://politicsir.cass.anu.edu.au/research/projects/ atrocity-forecasting/forecasts.

Azam, Jean-Paul and Anke Hoeffler. "Violence Against Civilians in Civil Wars: Looting or Terror?" Journal of Peace Research 39, no. 44 (2002), 461-485. Doi: 10.1177/0022343302039004006

Baudains, Peter, Shane D. Johnson, and Alex Maves Braithwaite. "Geographic Patterns of Diffusion in the 2011 London Riots." Applied Geography 45 (2013), 211-219. Doi: 10.1016/j. apgeog.2013.09.010

Bećirević, Edina. Genocide on the Drina River. New Haven: Yale University Press, 2014.

Bohara, Alok K., Neil J. Mitchell, and Mani Nepal. "Opportunity, Democracy, and the Exchange of Political Violence: A Subnational Analysis of Conflict in Nepal." Journal of Conflict Resolution 50, no. 1 (2006), 108-128. Doi: 10.1177/0022002705282872

Buhaug, Halvard and Jan Ketil Rød. “Local Determinants of African Civil Wars, 1970-2001.” Political Geography 25, no. 3 (2006), 315-335. Doi: 10.1016/j.polgeo.2006.02.005

Buhaug, Halvard, Scott Gates, and Päivi Lujala. "Geography, Rebel Capability, and the Duration of Civil Conflict." Journal of Conflict Resolution 53, no. 4 (2009), 544-569. Doi: 10.1177/0022002709336457

Croicu, Mihai and Ralph Sundberg. UCDP Georeferenced Event Dataset Codebook. Version 5.0. Uppsala: Department of Peace and Conflict Research, Uppsala University, 2016.

Cronin, Bruce. Bugsplat: The Politics of Collateral Damage in Western Armed Conflicts. New York: Oxford University Press, 2018.

Davenport, Christian. "State Repression and Political Order." Annual Review of Political Science 10 (2007), 1-23.

Des Forges, Allison. Leave None the Tell the Story: Genocide in Rwanda. New York: Human Rights Watch, 2010.

Easterly, William, Roberta Gatti, and Sergio Kurlat. "Development, Democracy, and Mass Killing."

${ }^{76}$ Saskia Sassen, The Global City: New York, London, Tokyo (Princeton: Princeton University Press, 2001), 3-16. 
Journal of Economic Growth 11, no. 2 (2006), 129-156. Doi: 10.1007/s10887-006-9001-z

Esteban, Joan, Massimo Morelli, and Dominic Rohner. "Strategic Mass Killings." Journal of Political Economy 123, no. 5 (2015), 1087-1132. Doi: 10.1086/682584

Fein, Helen. "Accounting for Genocide after 1945: Theories and Some Findings." International Journal on Group Rights 1, no. 2 (1993), 79-106. Doi: 10.1163/157181193x00013

Fjelde, Hanne and Nina von Uexkull. "Climate Triggers: Rainfall Anomalies, Vulnerability and Communal Conflict in Sub-Saharan Africa." Political Geography 31, no. 7 (2012), 444-453. Doi: 10.1016/j.polgeo.2012.08.004

Flint, Julie. Beyond "Janjaweed": Understanding the Militias of Darfur. Geneva: Small Arms Survey, 2009.

Gleditsch, Kristian Skrede. "Transnational Dimensions of Civil War." Journal of Peace Research 44, no. 3 (2007), 293-309. Doi: 10.1177/0022343307076637

Goldsmith, Benjamin E., Charles R. Butcher, Dimitri Semenovich, and Arcot Sowmya. "Forecasting the Onset of Genocide and Politicide: Annual Out-of-Sample Forecasts on a Global Dataset, 1988-2003." Journal of Peace Research50, no.44(2013), 437-452. Doi:10.1177/0022343313484167

Goodale, Mark. "Locating Rights: Envisioning Law Between the Global and the Local." In The Practice of Human Rights: Tracking Law Between the Global and the Local, edited by Mark Goodale and Sally Engle Merry, 1-38. New York: Cambridge University Press, 2007. Doi: 10.1017/cbo9780511819193.001

Goodwin, Jeff. “A Theory of Categorical Terrorism.” Social Forces 84, no. 4 (2006), 2027-2046.

Gould, Roger V. "Revenge as Sanction and Solidarity Display: An Analysis of Vendettas in Nineteenth-Century Corsica." American Sociological Review 65, no. 5 (2000), 682-704. Doi: $\underline{10.2307 / 2657542}$

Genocide Prevention Advisory Network. “Home." Accessed August 4, 2019. GPAnet.org

Harff, Barbara. "No Lessons Learned from the Holocaust? Assessing Risks of Genocide and Political Mass Murder since 1955." American Political Science Review 97, no. 1 (2003), 57-73. Doi: $10.1017 / \mathrm{s} 0003055403000522$

Hinton, Alexander Laban. "Critical Genocide Studies." Genocide Studies and Prevention 7, no. 1 (2012), 4-15.

Hultman, Lisa. "Battle Losses and Rebel Violence: Raising the Costs for Fighting." Terrorism and Political Violence 19, no. 2 (2007), 205-222. Doi: 10.1080/09546550701246866

. "Attacks on Civilians in Civil War: Targeting the Achilles Heel of Democratic Governments." International Interactions 38, no. 2 (2012), 164-181. Doi: 10.1080/03050629.2012.657602

Humphreys, Macartan and Jeremy M. Weinstein. "Handling and Manhandling Civilians in Civil War." The American Political Science Review 100, no. 3 (2006), 429-447. Doi: 10.1017/ $\underline{\text { s0003055406062289 }}$

International Association of Genocide Scholars. "Resolution on ISIS." 2016. Accessed August 4, 2019. www.genocidescholars.org/resources/resolutions.

Kalyvas, Stathis N. The Logic of Violence in Civil War. New York: Cambridge University Press, 2006.

Kalyvas, Stathis N. and Matthew Adam Kocher. "The Dynamics of Violence in Vietnam: An Analysis of the Hamlet Evaluation System (HES)." Journal of Peace Research 46, no. 3 (2009), 335-355. Doi: 10.1177/0022343309102656

Kim, Nam Kyu. "Revolutionary Leaders and Mass Killing." Journal of Conflict Resolution 62, no. 2 (2018), 289-317. Doi: 10.1177/0022002716653658

Krain,Matthew. "State-SponsoredMassMurder:TheOnsetandSeverityofGenocidesandPoliticides." Journal of Conflict Resolution 41, no. 3 (1997), 331-360. Doi: 10.1177/0022002797041003001

-------. "The Effects of Diplomatic Sanctions and Engagement on the Severity of Ongoing Genocides or Politicides." Journal of Genocide Research 16, no. 1 (2014), 25-53.

-------. "The Effect of Economic Sanctions on the Severity of Genocides or Politicides." Journal of Genocide Research 19, no. 1 (2017), 88-111. Doi: 10.1080/14623528.2016.1240516

Krcmaric, Daniel. "Varieties of Civil War and Mass Killing: Reassessing the Relationship between Guerrilla Warfare and Civilian Victimization." Journal of Peace Research 55, no. 1 (2018), 18-31. Doi: $10.1177 / 0022343317715060$ 
Loyle, Cyanne. "Understanding Nonstate Actor Behavior: The Determinants of Mass Atrocities." Simon-Skjodt Center for the Prevention of Genocide Series of Occasional Papers, no. 9 (2018), 1-22.

Massey, Doreen. A Global Sense of Place. Minneapolis: University of Minnesota Press, 1994.

McDoom, Omar Shahabudin. "Predicting Violence within Genocide: A Model of Elite Competition and Ethnic Segregation from Rwanda." Political Geography 42 (2014), 34-45. Doi: 10.1016/j. polgeo.2014.05.006

Moradi, Fazil and Kjell Anderson. "The Islamic State's Yazidi Genocide in Iraq: The Sinjar Operations." Genocide Studies International 10, no. 2 (2016), 121-138. Doi: 10.3138/gsi.10.2.02

Newbury, Catharine. "Background to Genocide: Rwanda." African Issues 23, no. 2 (1995), 12-17.

Nyseth Brehm, Hollie. "Conditions and Courses of Genocide." PhD diss., University of Minnesota, 2014.

"Re-examining Risk Factors of Genocide." Journal of Genocide Research 19, no. 1 (2017), 6187. Doi: 10.1080/14623528.2016.1213485

--------. "Subnational Determinants of Killing in Rwanda." Criminology 55, no. 1 (2017), 5-31. Doi: $\underline{10.1111 / 1745-9125.12126}$

Østby, Gudrun, Henrik Urdal, Mohammad Zulfan Tadjoeddin, S. Mansoob Murshed, and Håvard Strand. "Population Pressure, Horizontal Inequality and Political Violence: A Disaggregated Study of Indonesian Provinces, 1990-2003." The Journal of Development Studies 47, no. 3 (2011), 377-398. Doi: 10.1080/00220388.2010.506911

Political Instability Task Force (PITF). State Failure Problem Set. 2017.

Raleigh, Clionadh and Håvard Hegre. "Population Size, Concentration, and Civil War: A Geographically Disaggregated Analysis." Political Geography 28, no. 4 (2009), 224-238. Doi: 10.1016/j.polgeo.2009.05.007

Rapoport, David C. "The Four Waves of Rebel Terror and September." Anthropoetics 8, no. 1 (2002). Accessed August 4, 2019. www.wrldrels.org/wp-content/uploads/2016/02/Rapoport-FourWaves-of-Terror.pdf.

Rost, Nicolas. "Will It Happen Again? On the Possibility of Forecasting the Risk of Genocide." Journal of Genocide Research 15, no. 1 (2013), 41-67. Doi: 10.1080/14623528.2012.759398

Rummel, Rudolph J. Death by Government. New York: Transaction Publishers, 1997.

Rustad, Siri, Camilla Aas, Halvard Buhaug, Åshild Falch, and Scott Gates. "All Conflict is Local Modeling Sub-National Variation in Civil Conflict Risk." Conflict Management and Peace Science 28, no. 1 (2011), 15-40. Doi: 10.1177/0738894210388122

Salehyan, Idean. "The Delegation of War to Rebel Organizations." Journal of Conflict Resolution 54, no. 3 (2010), 493-515. Doi: 10.1177/0022002709357890

Sassen, Saskia. The Global City: New York, London, Tokyo. Princeton: Princeton University Press, 2001.

Sherman, Lawrence W. "Hot Spots of Crime and Criminal Careers of Places." Crime and Place 4 (1995), 35-52.

Schwartz, Rachel A. and Scott Straus. "What Drives Violence against Civilians in Civil War? Evidence from Guatemala's Conflict Archives." Journal of Peace Research 55, no. 2 (2018), 222-235. Doi: 10.1177/0022343317749272

Soto, Carlos Rodriguez. Tall Grass: Stories of Suffering and Peace in Northern Uganda. Kampala: Fountain Publishers, 2009.

Straus, Scott. “Triggers of Mass Atrocities." Politics and Governance 3, no. 3 (2015), 5-15.

--------. The Order of Genocide: Race, Power, and War in Rwanda. Ithaca: Cornell University Press, 2006.

Tagay, Sefik, Dogan Ayhan, Claudia Catani, Ulrich Schnyder, and Martin Teufel. “The 2014 Yazidi Genocide and its Effect on Yazidi Diaspora." The Lancet 390, no. 10106 (2017), 1946. Doi: 10.1016/s0140-6736(17)32701-0

United Nations Human Rights Council. "They Came to Destroy: ISIS Crimes Against the Yazidis." Advance Version, (2016), 1-41. UN Doc. A/HRC/32/CRP.2.

Uzonyi, Gary. "Civil War Victory and the Onset of Genocide and Politicide." International Interactions 41, no. 2 (2015), 365-391. Doi: 10.1080/03050629.2014.932786

. "Domestic Unrest, Genocide and Politicide." Political Studies 64, no. 2 (2016), 315-334. Doi: $\underline{10.1111 / 1467-9248.12181}$ 
Valentino, Benjamin, Paul Huth, and Dylan Balch-Lindsay. "'Draining the Sea': Mass Killing and Guerrilla Warfare." International Organization 58, no. 2 (2004), 375-407. Doi: 10.1017/ $\underline{\text { s0020818304582061 }}$

Valentino, Benjamin. "Triggers of Mass Killing." Report on a Research Project for the Political Instability Task Force. Hanover: Dartmouth College, February 2016.

---------. “Why We Kill: The Political Science of Political Violence against Civilians." Annual Review of Political Science 17, no. 1 (2014), 89-103. Doi: 10.1146/annurev-polisci-082112-141937

Walter, Barbara F. "Designing Transitions from Civil War: Demobilization, Democratization, and Commitments to Peace." International Security 24, no. 1 (1999), 127-155. Doi: $10.1162 / 016228899560077$

"The New New Civil Wars." Annual Review of Political Science 20 (2017), 469-486.

Ward, Michael D., Brian D. Greenhill, and Kristin M. Bakke. "The Perils of Policy by P-Value: Predicting Civil Conflicts." Journal of Peace Research 47, no. 4 (2010), 363-375. Doi: 10.1177/0022343309356491

Weinstein, Jeremy M. Inside Rebellion, The Politics of Insurgent Violence. New York: Cambridge University Press, 2007.

Weitz, Eric D. A Century of Genocide. Princeton: Princeton University Press, 2003.

Whitmore, Todd David. "Genocide or Just Another 'Casualty of War'? The Implications of the Memo Attributed to President Yoweri K. Museveni of Uganda." Practical Matters 3 (2010), $1-49$.

Williams, Timothy. "More Lessons Learned from the Holocaust: Towards a Complexity- Embracing Approach to Why Genocide Occurs." Genocide Studies and Prevention 9, no. 3 (2016), 137153. Doi: 10.5038/1911-9933.9.3.1306

Wood, Elisabeth Jean. Insurgent Collective Action and Civil War in El Salvador. New York: Cambridge University Press, 2003.

Wood, Reed M. "Rebel Capability and Strategic Violence against Civilians." Journal of Peace Research 47, no. 5 (2010), 601-614. Doi: 10.1177/0022343310376473

Yazda Documentation Project. Mass Graves of Yazidis Killed by the Islamic State Organization or Local Affiliates On or After August 3, 2014. Yazda: Global Yazidi Organization, 2016. 